Article

\title{
Registration of Atmospheric-Electric Effects from Volcanic Clouds on the Kamchatka Peninsula (Russia)
}

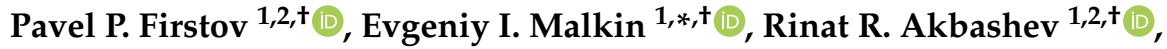 \\ Gennadiy I. Druzhin ${ }^{1,+}\left(\mathbb{0}\right.$, Nina V. Cherneva ${ }^{1,+}+{ }^{+}$, Robert H. Holzworth ${ }^{3,+} \oplus$, \\ Vladimir N. Uvarov ${ }^{1,+}$ and Ivan E. Stasiy ${ }^{1}$ \\ 1 Institute of Cosmophysical Research and Radio Wave Propagation FEB RAS, Paratunka 684034, Russia; \\ firstov@emsd.ru (P.P.F.); arr@emsd.ru (R.R.A.); drug@ikir.ru (G.I.D.); nina@ikir.ru (N.V.C.); \\ uvarovvnng@yandex.ru (V.N.U.); adjanty@gmail.com (I.E.S.) \\ 2 Kamchatka branch of the Federal Research Center "Unified Geophysical Service of the RAS", \\ Petropavlovsk-Kamchatsky 683006, Russia \\ 3 Earth and Space Sciences, University of Washington, Seattle, WA 98195-1310, USA; bobholz@uw.edu \\ * Correspondence: malkin@ikir.ru \\ + These authors contributed equally to this work.
}

Received: 20 February 2020; Accepted: 10 June 2020; Published: 15 June 2020

\begin{abstract}
The paper is devoted to the description of observations over atmospheric and electric effects from volcanic eruptions on Kamchatka peninsula (Russia) and perspectives of their development. To collect information about atmospheric-electric effects accompanying the eruptions of Kamchatka volcanoes, three sensor networks and a VLF radio direction finding station are used. The World Wide Lightning Location Network (WWLLN) provides information on high-current lightning discharges that occur during the development of an eruptive cloud (EC). Variations in the electric field of the atmosphere (AEF $E_{z}$ ), during the passage of EC, were obtained by a network of electric field mills at the sites for volcanic activity observations. Seismic detector network was used to make precision reference to the eruptions. Based on the data obtained, a description is given of the dynamics of eruptions of the most active volcanoes in Kamchatka and the Northern Kuril Islands (Shiveluch, Bezymianny, Ebeko). The paper presents a simulation of the response of the atmospheric electric field, which showed that the approximation by the field of distributed charges makes it possible to estimate the volume charges of EC. The fact of a multi-stage volcanic thunderstorm is confirmed. The first stage is associated with the formation of an eruptive column, and the second with the emergence, development and transfer of EC. Registration of electrical and electromagnetic processes in eruptive clouds can be one of the components of complex observations of volcanic eruptions in order to assess the ash hazard for air transport.
\end{abstract}

Keywords: volcanic eruptions; atmospheric electric field; volcanic lightning

\section{Introduction}

During explosive volcanic eruptions, magma fragmentation (destruction) followed by eruptive column and eruptive cloud formation is accompanied by electrification with discharges of different intensity occurring as a result of different physical processes [1-4].

Significant intensity of the electric field in an eruptive column and, subsequently, in an eruptive cloud results in the formation of electric strokes of different intensity. During St. Augustine volcano (Alaska) eruption on 11-28 January 2006, it was observed on the same-name island near Alaska coast that lightning strokes had two phases. The first one coincides with eruption beginning and the second one begins 4-12 $\mathrm{min}$. after the eruption beginning [5]. Based on the results of radio source locations 
in ultra-short wave (USW) range (30-300 MHz), the impulses emitted by volcanic lightning were conditionally divided into three types [2]. Later, in the paper [6] the authors analyzed Redoubt volcano eruption on 23-29 March 2009 and described in detail:

- vent strokes-strokes recorded at the initial stage of eruptive column formation, their duration was about $10^{-4} \mathrm{~s}$ that corresponds to lightning channel of the length of 10-100 m;

- near-vent discharges-discharges recorded in an eruptive column whith a duration of 0.01-0.1 (s) and lightning channel length of 1-7 km;

- plume lightning-classical lightning strokes similar to those recorded in atmospheric clouds, this type of strokes develops when EC reaches buoyancy region with plume formation, EP duration is more than 0.1 (s) that corresponds to a lightning channel of the length of more than $10 \mathrm{~km}$.

Thus, when observing lightning activity in the region of active volcanoes, we can monitor effectively the presence of volcanic activity. The importance of such observations on Kamchatka peninsula is determined by the closeness of active volcanos to international air ways [6-8].

Lightning is observed by ground-based networks for lightning location such as WWLLN. WWLLN is operating in the range of very low frequencies (VLF) and in order to locate source locations, it applies methods for determining the time of group arrival (TOGA) of lightning stroke wide-band pulse radiation. That allows us to record EP with the accuracy up to several microseconds [9] and to determine the locations of strokes from strong volcanic lightning (lightning stroke occurring in an eruptive cloud) to monitor eruptive cloud propagation $[8,10,11]$. However, as it was shown in [3], the efficiency of WWLLN detection is $26 \%$ for cloud-ground lightning and $10 \%$ for cloud-cloud lightning. That is why in addition to WWLLN data we apply the data obtained by VLF radio direction finder developed by the authors.

During eruptive cloud distribution, erupted material fractionate. The largest particles fall near a volcano and ash smaller particles and aerosols propagate for hundreds and in some cases for thousands of kilometers under wind effect. Owing to ash mass decrease in an eruptive cloud and its cooling, lightning activity of the cloud decreases. As a result, lightning activity analysis can give a picture on eruptive cloud propagation at the distance of about $100 \mathrm{~km}$ from the volcano. However, the absence of lightning activity does not mean total loss of charge. That is why the extended ground network of electric field mills aimed at measuring quasi-static electric field may give additional information on further propagation of an eruptive cloud with low concentration of fine-grained ash [1,6-8].

The paper is devoted to the description of modern observations of atmospheric and electrical effects (changes of potential gradient and lightning activity) from volcano eruptions on the Kamchatka peninsula (Russian) and prospective of their development.

\section{Results}

\subsection{Instrumentation and Observation Method}

As a rule, geodynamic processes, to which we can attribute earthquakes and volcano eruptions, are accompanied by the interaction of geosphere sells. Such interactions manifest as disturbances in geophysical fields of different nature including those in atmospheric electric field (AEF) [12]. Monitoring of AEF $E_{Z}$ allows one to record such disturbances. For this purpose, a site network for $\mathrm{AEF} E_{Z}$ observations was created near active volcanoes on the Kamchatka peninsula and Paramushir Island. Observation sites were organized at seismic stations of Kamchatka Branch of the Geophysical Survey of the Russian Academy of Sciences (KB GS RAS) and at a seismic station of Sakhalin Branch of the Geophysical Survey of the Russian Academy of Sciences (SB GS RAS) (Figure 1a):

1. KLY-Klyuchi. Operating since 2013.

2. KZY-Kozyrevsk. Operating since 2013. 
3. KBG-Krutoberegovo. Operating since 2016.

4. SKR-Severo-Kuril'sk. Operating since 2018.

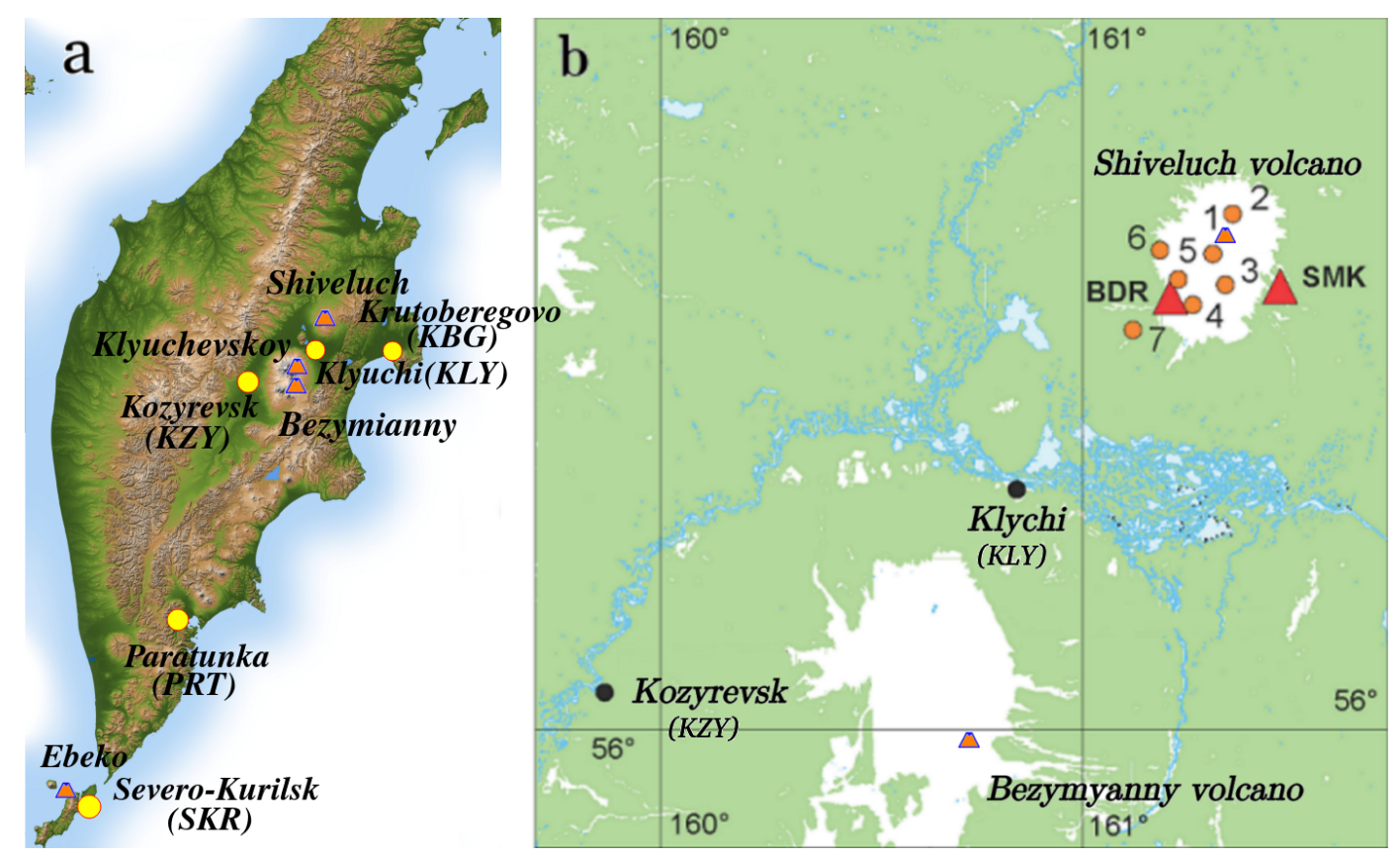

Figure 1. A scheme of location of Shiveluch, Klyuchevskoi, Bezymianny and Ebeko volcanoes (marked as $\Delta$ ) and the sites recording atmospheric-electric effects in Kamchatka atmosphere (marked as $\circ$ ) (a), observation sites for volcanoes and the Northern group of volcanoes and lightning discharges (1-7) recorded by WWLLN network during Shiveluch volcano eruption on 16 November 2014 (b).

\subsubsection{Instrumentation and Observation Method of Electric Field Vertical Component}

In order to automate the process of data acquisition and preliminary processing, a hardware-software complex was developed on the basis of electrostatic flux meter EF-4 [13], providing AEF $E_{Z}$ records in the range up to $\pm 7 \mathrm{kV} / \mathrm{m}, \mathrm{ADC}$ by L-Card and microcomputer of Thiner Board series by Asus [14]. The developed complex improves operation control of equipment functioning and provides data transmission to the servers in the mode close to real time.

There are seismic stations, channels for atmospheric infrasonic signal recording at the sites. Video monitoring of active volcanoes is continuously carried out there. Autonomous seismic stations are working near the volcanoes.

Eruptive clouds (EC) are formed and propagate in the conditions of atmosphere stratification. Data balloon sounding which takes place twice a day at the meteorological observatory in Klyuchi (Kamchatka Division on Hydrometeorology and Environment Monitoring) make it possible to determine the direction and propagation velocity of EC from explosive eruptions of the Northern Group of Volcanoes (https:/ / ruc.noaa.gov/raobs/). Thus, signals in AEF $E_{Z}$ records associated with eruptive cloud passage were selected on the basis of complex analysis of seismic, infrared, infrasonic, satellite, meteorological and video observation data.

\subsubsection{Instrumentation and Observation Method of Lightning Discharges}

The World Wide Lightning Location Network (WWLLN) allows us to record EP from lightning discharges over the whole planet. As long as WWLLN stations are located at large distances from Kamchatka, this network records only powerful lightning strokes occurring in EC of Kamchatka volcanoes $[7,10]$. Nevertheless, lightning recorded by the WWLLN are exact markers of eruptive events $[7,11,15]$. Figure $1 \mathrm{~b}$ shows an example of lightning stroke location by the WWLLN during Shiveluch volcano eruption on 16 November 2014. As it was mentioned before, a VLF radio 
direction finder, developed at IKIR FEB RAS is mainly used to analyze EC lightning activity. It is installed at an expedition site near Karymshina river $\left(\phi=52^{\circ} 49^{\prime} \mathrm{N}, \lambda=158^{\circ} 07^{\prime}\right.$ E) located near Paratunka village (Figure 1a, PRT) [16,17]. The VLF radio direction finder includes an antenna system, preamplifiers, dedicated cable line for analogue signal transmission, analogue-to-digital converter, microcomputer, software complex for digital data processing and transmission. The antenna system consists of two mutually-perpendicular frame magnetic antennas and one vertical rode electric antenna. The magnetic antennas are arranged vertically and their plane is oriented in the north-southern (the first) and east-western (the second) directions. The sensitivity threshold of the complex is not less than $0.1 \mathrm{~V} / \mathrm{m}$ in the electric field and is not less than $2 \cdot 10^{-7} \mathrm{nT} \cdot \mathrm{Hz}^{-1 / 2}$ in the magnetic field. Such small sensitivity thresholds allow one to record very weak strokes from volcanic lightning. Magnetic antennas allows one to simultaneously measure two orthogonal components of magnetic field. Owing to that we can recover the vector of pulse radiation energy flux density. When we take into account antenna transmission coefficients and radiation polarization, that allows us to improve the accuracy of determining the azimuth of electromagnetic wave arrival.

\subsection{Brief Characteristics of Activivty of Some Volcanoes in Kamchatka and North Kurils}

There are 30 active volcanoes on Kamchatka peninsula.The most active of them are the Shiveluch, Klyuchevskoy, Bezymianny and Tolbachik volcanoes which form the Northern Group of Volcanoes (Figure 1a,b).

The most northern active andesitic volcano of Kamchatka, the Shiveluch volcano, is a lost volcano of the age of $\sim 60-70$ thousand years with the bases of $45 \times 40 \mathrm{~km}$ and the area of not less than $1300 \mathrm{~km}^{2}$. The latest catastrophic eruption which occurred on 12 November 1964 destroyed several domes and formed a crater with the size of $1.5 \times 3.0 \mathrm{~km}$ [18].

After the 16-year gap in volcano eruption, since August 1980 up to the present time, an extrusive dome is growing within the new crater with short pauses. Since August 1980 up to the present time, except for some short periods, explosive eruptions associated with explosive dome growth are typical for Shiveluch volcano.

In this case eruptive cloud height may reach 10-12 km above the sea level. Ash plume propagate for hundreds of kilometers. Events of such a type refer to "volcanic" type of eruptions and can be quite useful for natural observations of atmospheric-electric effects [19].

Frequent explosive eruptions occur on Bezymianny volcano on which a paroxysmal eruption occurred on 30 March 1956. In the result of it, a crater with the size of $1.5 \times 2.8 \mathrm{~km}^{2}$ and the depth of $700 \mathrm{~m}$ was formed on the peak position. At the present time an extrusive dome has been formed in the crater, on which strong explosive eruptions periodically occur with the formation of pyroclastic flows, as a rule [18].

The erupting stratovolcano Ebeko on Paramushir Island consists of several quaternary volcanic cones. It is located in the northern part of Vernadskiy ridge on Paramushir Island, $7 \mathrm{~km}$ to the west from Severo-Kuril'sk (SKR) (Figure 1a). Ebeko peak includes three abutting craters with the diameters of 250-300 m. They are the sources of explosions with lightning activity (https://www.youtube. $\mathrm{com} /$ watch?v=upX-qyLM764). During the latest centuries, Ebeko volcano eruptions can be referred only to explosive phreatic or phreatic-magmatic ones the duration of which is $2-4$ years as a rule. Inter-eruption activity periods are $20-30$ years [20,21]. Granulometric, chemical, mineral content of tephra for the latest eruptions of Ebeko volcano does not almost change. Tephra is mainly represented by resurgent material. Juvenile rocks were insignificant or absent.

The latest eruption which is taking place now began on 8 November 2016. Weak explosions with different ash loading occur from different eruptive centers both one-by-one and simultaneously. Eruptive cloud (EC) height can reach $4 \mathrm{~km}$ above the sea level. According to the data [22], $80 \%$ of tephra has the particle size of less than $0.25 \mathrm{~mm}$ that means that it is mainly represented by volcanic ash. Large pieces are represented by porous andesite, andesite-basalt. Fine ash is the product of this rock breaking. There are pieces of brown glass foam in the volume of $1-3 \%$ from a sample. Fresh glass 
was not observed in the samples. According to chemical and mineral content, fresh tephra refers to dacite-andesite and the most acid difference refers to dacite. The further from volcano was, the more acid content the ash had.

Ebeko volcano was considered by the authors as a natural laboratory for natural investigations of atmospheric-electric effects from weak explosive eruptions.

\subsubsection{Observations of Electric Field Vertical Component on Kamchatka Peninsula and Paramushir Island}

Besides the traditional tasks of atmospheric electricity (investigation of unitary variation, global electric circuit mechanisms, etc.), the data from the sites of AEF $E_{z}$ observations allow us to investigate atmospheric-electric effects occurring during formation and propagation of eruptive clouds from volcano explosive eruptions. Examples of recording the response AEF $E_{z}$ when a cloud moves above ground electric field mills. In the result of electric field mills operation in the region of the Northern group of volcanoes from 2013 to 2019, responses during eruptive cloud passage from 4 strong explosive eruptions of Shiveluch volcano were recorded $[19,23]$. Table 1 shows the main parameters of the anomalies in AEF $E_{z}$ associated with the responses on EC passage.

Table 1. Parameters of AEF $E_{z}$ signals recorded at ground-based sites during eruptive cloud passage from Shiveluch volcano eruptions.

\begin{tabular}{|c|c|c|c|c|c|c|c|c|c|}
\hline \multirow[b]{2}{*}{ No } & \multirow[b]{2}{*}{ Data } & \multirow[b]{2}{*}{$t_{0}$} & \multicolumn{3}{|c|}{ KZY } & \multicolumn{4}{|c|}{ KLY } \\
\hline & & & Polarity & $E_{\text {max }}^{Z}, V / m$ & $t_{d}$ & polarity & $E_{\text {max }}^{Z}, V / m$ & $t_{d}$ & $\delta$ \\
\hline 1 & 16.11 .2014 & $10: 17: 55$ & + & 170 & 85 & \multicolumn{4}{|c|}{ Site did not work } \\
\hline 2 & 16.12.2016 & $22: 31: 32$ & \multicolumn{3}{|c|}{ Cloud passed by } & - & -1249 & 51 & 20 \\
\hline 3 & 14.06 .2017 & $16: 26: 37$ & + & +1082 & 140 & \pm & $\begin{array}{r}-5877 \\
+4820 \\
\end{array}$ & $\begin{array}{l}40 \\
34\end{array}$ & $\sim 100$ \\
\hline 4 & 30.12 .2018 & $00: 34: 46$ & \multicolumn{3}{|c|}{ Cloud passed by } & - & -588 & 90 & 80 \\
\hline
\end{tabular}

Note. $t_{0}$ is the eruption beginning time (hh:mm:ss); $t_{d}$ is the signal duration, min; $\delta$ is the total amount of fallen ash in KLY sites, $\mathrm{g} / \mathrm{m}^{2}$.

The most interesting event occurred during the Shiveluch volcano eruption on 14 June 2017 at 16:26 (UT). EC passed over the observation sites KLY and KZY at the height of $\sim 12 \mathrm{~km}$ (http://www.emsd.ru/ ssl/monitoring/main.htm). It is clear on HIMAWARI-8 satellite images (http: / / rammb.cira.colostate.edu/) that 34 min after the eruption beginning, a nearly circular umbrella cloud with the diameter of $\sim 70 \mathrm{~km}$ was formed at the height of $9 \mathrm{~km}$ (Figure 2a). It spread out during the motion to KLY with the velocity of $12 \mathrm{~m} / \mathrm{s}$ (Figure $2 \mathrm{a}-\mathrm{c}, \mathrm{g}$ ). EC formation and propagation were recorded by a video camera in KLY (Figure $2 \mathrm{~d}-\mathrm{f}$ ). Almost one hour later, the EC covered the settlement where $\sim 100 \mathrm{~g} / \mathrm{m}^{2}$ of ash fell. Then it continued moving to the south in the direction of Klyuchevskoy volcano (Figure 2f). At 21:33, when the eruptive cloud reached KZY site, weak precipitation of fine-grained ash was observed [19].

The amplitude of the explosive earthquake at SMK from the eruption on June 14 June 2017 exceeded the dynamic range limited by the value of $40 \mu \mathrm{m} / \mathrm{s}$, and its duration was $\sim 10$ min (Figure 3a). The eruption was accompanied by an air shock wave which evolved with distance into an infrasonic one and was recorded by all microbarograph channels on Kamchatka peninsula. Figure $7 \mathrm{~b} .3$ shows the time of shock wave arrival to KLY site. Based on the parameters of seismic and acoustic channels we can state that the explosion on Shiveluch volcano on 14 June 2017 began with a powerful burst after which gradually attenuating outflow of the ash-gas mixture from the volcano crater was taking place for $10 \mathrm{~min}$. The successful combination of "fair weather conditions" and wind direction during the eruption allowed us to record the response in AEF $E_{z}$ during EC passage over KLY and KZY. 

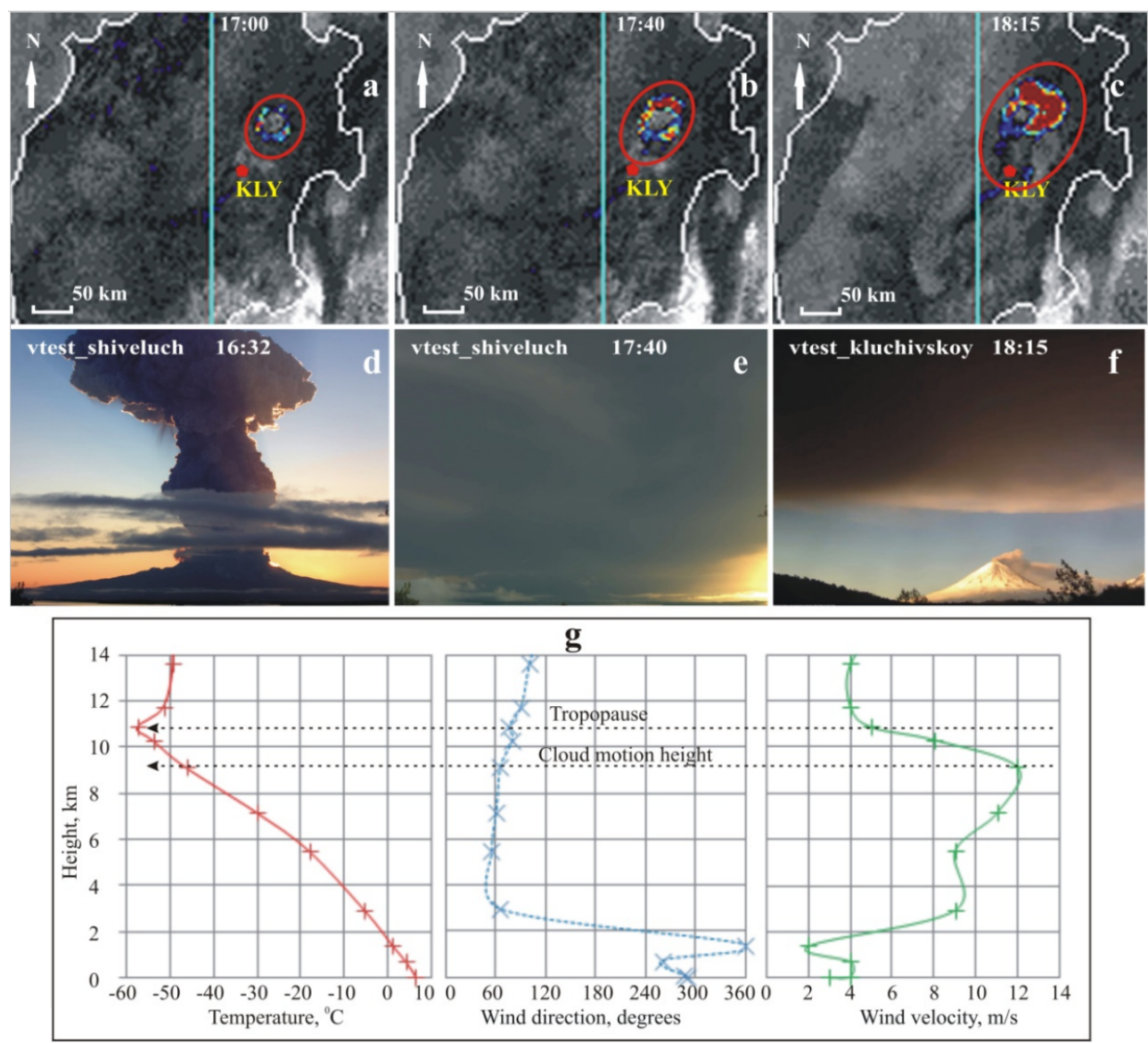

Figure 2. Propagation of an eruptive cloud from Shiveluch volcano eruption on 14 June 2017 according to the data of HIMAWARI-8 satellite images (a,c) (http:/ / rammb.cira.colostate.edu); development of an eruptive cloud recorded by a video camera at $\operatorname{KLY}\left(56.318439^{\circ} \mathrm{N}, 160.855891^{\circ} \mathrm{E}\right.$, the distance from the observation point to the Shiveluch volcano is $45 \mathrm{~km})(\mathbf{d}, \mathbf{f})$; temperature and wind stratification of the atmosphere according to balloon sounding data $(\mathrm{g})$.

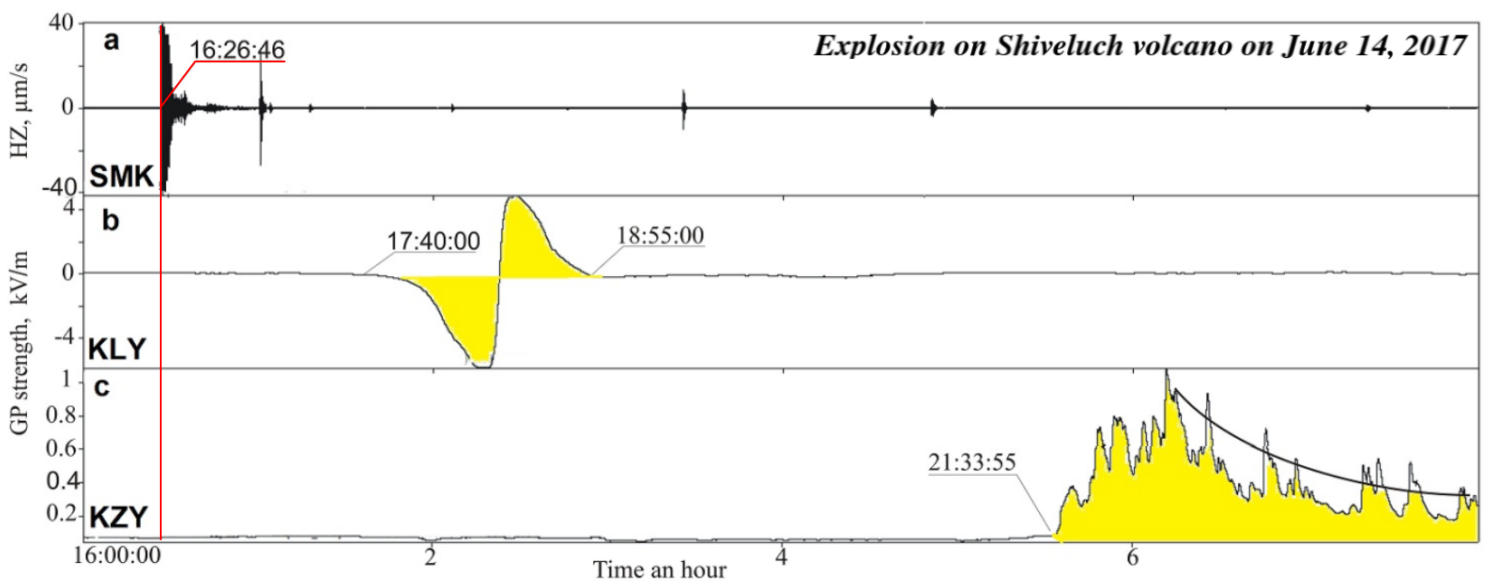

Figure 3. Record fragments: ground displacement shift of the vertical component at $\operatorname{SMK}(\mathbf{a}) ; \operatorname{AEF} E_{Z}$ strength at KLY (b) and KZY (c), time indicated in the figure according to UT.

At a wind speed of $\sim 12 \mathrm{~m} / \mathrm{s}$ (Figure $2 \mathrm{~g}$ ), an eruptive cloud, $62 \mathrm{~min}$ after the start of the eruption (Table 1), passed over KLY. From the time of ash fall at 17:40 at KLY, AEF $E_{Z}$ began to decrease to $-6 \mathrm{kV} / \mathrm{m}$, and then sharply increased to $+5 \mathrm{kV} / \mathrm{m}$ (Figure $3 \mathrm{~b}$ ). The anomaly form reminds AEF $E_{Z}$ response from a horizontal dipole passing though a recording site with the axis oriented along the motion direction [24]. The dipole is likely to be formed due to the two-stage eruption followed by 
eolian differentiation as EC propagates. Thus, ash large particles were negatively charged in the front part of the EC and aerosol particles of the rest part of the cloud were positively charged. Applying the vertical sections of wind velocity direction (Figure $2 \mathrm{~g}$ ), as well as anomaly travel time characteristics, dipole charge was calculated. It was $q \approx 40 \mathrm{C}$ [12]. The higher amplitude of the negative phase in AEF $E_{Z}$ on 14 June 2017, compared to 16 December 2016 (Table 1), is likely to be caused by larger amount of ash fallen in KLY $\left(100 \mathrm{~g} / \mathrm{m}^{2}\right.$ against $\left.20 \mathrm{~g} / \mathrm{m}^{2}\right)$. The EC reached the KZY site on 4 June 2017 in $\sim 5 \mathrm{~h}$ where insignificant amount of fine-grained ash fell.Based on the form of anomaly back front at KZY with $E_{z . m a x} \approx 1.0 \mathrm{kV} / \mathrm{m}$ (Figure 3c) we can assume that it might be formed by positively-charged cloud passage [24]. Evidently, when propagating at long distances during eolian differentiation, EC develops into an aerosol cloud in which the main components are volcanic gases (up to 96-98\% $\mathrm{H}_{2} \mathrm{O}$ ) with insignificant content of very fine ash. At this stage of EC evolution, positive total charge, apparently, prevails in its aero-electric structure.

During the period from 1 October to 31 March 2019, 47 cases of responses in AEF $E_{Z}$ (Table 2) near Ebeco volcano during the EC passage over SKR were recorded. Useful signals were selected on the base of continuous monitoring of the volcano by a video camera installed at the seismic station. Explosions occurred during different meteorological conditions, both during fair weather and during bad weather conditions. For the cases shown in Figure 4, the stratification of the lower atmosphere almost coincided, to a height of $4 \mathrm{~km}$. The speed of air mass movement, at the height of hovering, was $\sim 2 \mathrm{~m} / \mathrm{s}$ and had a western direction.

Ash clouds sometimes produced unipolar negative field-changes (Figure 4a), and sometimes positive field changes (Figure $4 \mathrm{~b}$ ). Infrequently, they produced bipolar field changes (Figure 4c). The anomaly duration was from 10 to $30 \mathrm{~min}$ with the amplitude average of $\sim 1.0 \mathrm{kV} / \mathrm{m}$, and the maximum value of $\sim 3.0 \mathrm{kV} / \mathrm{m}$.

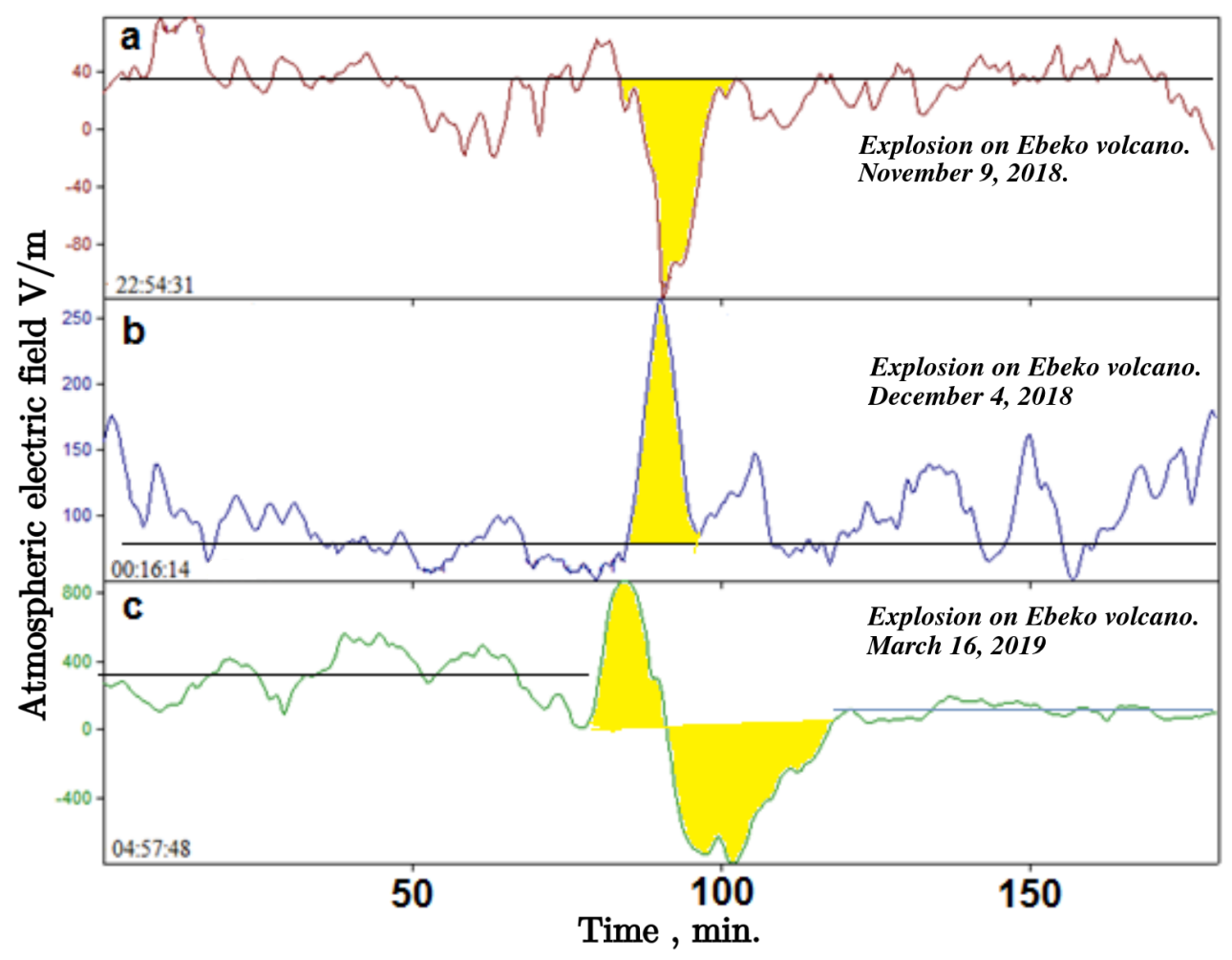

Figure 4. Examples of $\mathrm{AEF} E_{Z}$ responses with negative (a), positive (b) and alternating sign polarity of signals (c) occurring during gas-ash cloud passage from Ebeko volcano explosions over SKR.

Observation of three types of anomalies in AEF $E_{Z}$ (Figure 4) indicates the fact that both explosion with magma fragmentation and explosion with mainly gas phase outflow took place during the Ebeko 
volcano eruptions. This conclusion confirms the participation of water vapor in the process of charge separation in an eruptive cloud [25].

Table 2. The parameters of response in $\mathrm{AEF} E_{Z}$ recorded at SKR during the eruptive cloud passage from Ebeko volcano eruptions from 1 October 2018 to 31 March 2019.

\begin{tabular}{cccc}
\hline \multicolumn{4}{c}{ SKR Observation Site } \\
\hline & 9 November 2018 & 4 December 2019 & 16 March 2019 \\
\hline Signal polarity & “" & “-" & “ $\pm " ~$ \\
\hline Number of cases & 23 & 18 & 6 \\
\hline Average amplitude, $\mathrm{kV} / \mathrm{m}$ & $0.73 \pm 0.46$ & $-(0.89 \pm 0.44)$ & $\begin{array}{c}1.42 \pm 0.75 \\
-(0.78 \pm 0.36)\end{array}$ \\
\hline
\end{tabular}

Natural data of responses in $\mathrm{AEF} E_{Z}$ of ash-gas cloud passage from explosive eruptions are the basis for investigation of their fine aero-electric structure.

\section{Fine Aero-Electric Structure of an Eruptive Cloud}

Eruptive clouds are characterized by significant lateral extent (up to several hundreds of kilometers) at a comparatively small thickness (from hundreds of meters to several kilometers) $[26,27]$ and are characterized by spatial inhomogeneity of its electrostatic structure. It appears during eruptive cloud formation and motion under the effect of a number of physical processes such as: turbulence, occurring due to a hot EC exchange with ambient air; condensation of released steam with ice crystal formation; gravitational settling of ash particles [6]. Moreover, in case of long-lasting outflow of ash-gas mixture, changes in the mass flux at source occur that also generates electrostatic inhomogeneities in EC.

In order to construct a model for a charged EC, it is reasonable to refer to the notions known in electrostatics, in the basis of which is the approximation of a bounded domain uniformly charged by a point charge. Combination of such domains into more complicated configurations (dipoles, quadruples etc.) allows us to approximate a field of arbitrary configuration with the required accuracy. We shall call the EC volume with the characteristic size of spatial inhomogeneity a "volcanic globule" (VG).

As an example, we consider the AEF $E_{Z}$ at KZY site located $112 \mathrm{~km}$ to the Southwest from Shiveluch volcano during the passage of an EC from this volcano on 16 November 2014 at 10:18. At tropopause height of $9-11 \mathrm{~km}$, the wind velocity was $22-28 \mathrm{~m} / \mathrm{s}$ and air mass direction had the azimuth of $25^{\circ}$. These are the key meteorological parameters affecting eruptive cloud propagation. The response was observed in fair weather conditions and calm AEF $E_{Z}$ field with the amplitude of $\sim 60 \mathrm{~V} / \mathrm{m}$ [7]. At 10:45 first weak variations of AEF $E_{Z}$ were observed.At that time, the eruptive cloud was located at the distance of $\sim 60 \mathrm{~km}$ from the observation point. Almost two hours after the eruption, beginnings of two anomalies (12:04 and 13:10, point 3 and 5 in Figure 5a) were clearly observed. The total duration was about one hour and a half (Figure $5 a, b$ ), where as AEF $E_{Z}$ maximum reaches $\sim 170 \mathrm{~V} / \mathrm{m}$. It is clear in Figure $5 \mathrm{~b}$ that "higher-frequency" oscillations with the amplitude of $\sim 10 \mathrm{~V} / \mathrm{m}$ are observed before well-defined AEF $E_{Z}$ anomalies for $78 \mathrm{~min}$ (between the markers 1 and 3). The anomalies themselves are also complicated with "high-frequency" oscillations. A signal with the duration of more than three hours was divided into the parts and filtered with a high pass filter with $f_{l b}=0.0008333 \mathrm{~Hz}$ (20-min period). On the filtered signal, the detected sections are quite confidently distinguished according to the kinematical and dynamic parameters (Figure $5 b$ ). When comparing the volcanic plume structure with electromagnetic field response, we can notice the presence of VG of different sizes with different charge value. The charge value can be compared with the amplitude of the field induced by it and the VG diameter can be compared with the width of the curve in the extremum vicinity that allows us to interpret the results of $\mathrm{AEF} E_{Z}$ recording. For example, 
it was revealed from seismic data analysis that an ejection occurred at the beginning of the eruption. It lasted for about $25 \mathrm{~min}$ with increased activity period of about $12 \mathrm{~min}$. It formed a separate (VG). In Figure 5 this fact is represented in the form of a time interval from 10:45 (point 1) till 11:35 (point 2). The following period of turbulent weak outflow of pyroclastic masses (interval between 11:35 (point 2) and 12:03 (point 3)) was changed by a powerful ejection of pyroclastic material (interval between 12:03 (point 3) and 12:49 (point 4)). It was followed by an extensive lava outflow (interval between 12:49 (point 4) and 13:10 (point 5)). In that case intensive warmed air upstream was formed. It was rich in dispersion material and formed VG large enough in size and in charge (interval between 13:10 (point 5) and 13:42 (point 6)). The following variation of the curve after 13:42 (point 6) is associated with volcanic plume motion from the recording device. The data on eruption stages were obtained by direct observations at KLY site and confirmed by an expedition later.

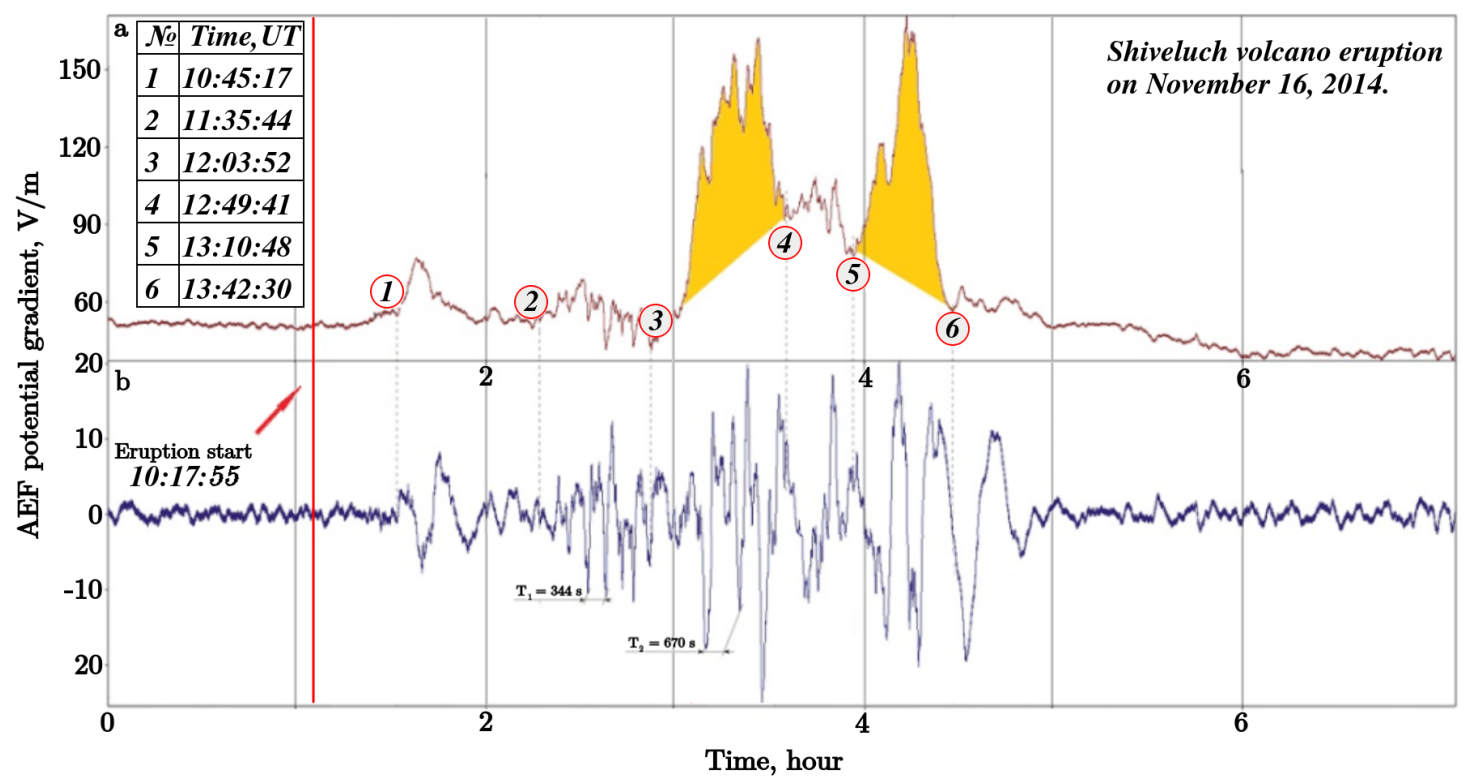

Figure 5. AEF $E_{Z}$ response on EC passage from Shiveluch volcano eruption with characteristic reference points at KZY site (a); the same but after the filtration by a high pass filter with $f_{l b}=0.0008333 \mathrm{~Hz}$ (20-min period (b) [7].

Analysis of field discrete source structures was carried out after their recovery by the continuous field generated by them. The simplest recoverable structure (atom) is a VG which has the charge $Q$ and dimension parameter $\gamma$.

Conversion to EC globular structure is similar to spectral analysis, to some extent. The field created by VG can be approximated by point charge field $Q_{g}$ :

$$
E_{z}=\frac{Q_{g}}{4 \pi \varepsilon_{0} R^{2}}
$$

where $R=\sqrt{x^{2}+y^{2}+z^{2}}, x, y, z$ are the VG coordinates.

There may be two parameters characterizing VG: diameter $\left(D_{g}\right)$ and charge $\left(Q_{g}\right)$, or a pair equivalent to it $D_{g}$ and charge density $\rho_{g}=Q_{g} / D_{g}^{3}$.

We choose the coordinates so that VG motion is directed along $X$ axis. In a general case, VG moves in a straight line not passing the observation point. Then on trajectory projection on a horizontal plane there is a point, which has the minimum distance to the observation site. Consequently, coordinate $\mathrm{x}$ can be determined from wind velocity $(v)$ and time, $x=v\left(t-t_{\text {extr }}\right)$, where $t_{\text {extr }}$ is the time instant corresponding to the minimum distance from the observation site to VG.

VG field over the conducting surface of the Earth is a field superposition of two charges, one directly from it and from a virtual charge induced by it. As long as the atmospheric air conductivity 
is many orders less than ground conductivity, we shall further consider the ground conductivity to be infinite. Then virtual charge position turns to be under the ground surface at the depth, equal to VG location height.

Field ground-based measurements are usually carried out at the ground level. Thus, field horizontal component is zero and electric field is represented only by vertical component. In this case, the VG field is approximated by the field of a symmetric dipole with the same charge but with the separation equal to the globule double height.

$$
E_{z}=\frac{Q_{g}}{2 \pi \varepsilon_{0}} \cdot \frac{z}{\left|R_{\min }^{3}\right|}
$$

We introduce the variables $R_{\min }=\sqrt{z^{2}+y^{2}}, \gamma=v / R_{\min }$ and write Equation (2) as

$$
E_{z}=\frac{Q_{g}}{2 \pi \varepsilon_{0}\left|R_{\text {min }}^{3}\right|} \cdot \frac{z}{\left(1+\left(\gamma\left(t-t_{\text {extr }}\right)\right)^{2}\right)^{3 / 2}}
$$

Based on the expression (3), we can determine the point charge value from electric field $E_{Z}$ extremum by the charge known location relatively the KZY site and by wind velocity

$$
Q_{g}=E_{z} 2 \pi \varepsilon_{0} \frac{\left|R_{\min }^{3}\right|}{z} \cdot\left(1+\left(\gamma\left(t-t_{\text {extr }}\right)\right)^{2}\right)^{3 / 2}
$$

Figure 6 shows the results of the electric field initial record, curve Coulomb approximation in the form of point charges, taking into account EC two extreme charges, and a graph of $E_{Z}$ values optimized by $\gamma$ approximation, considering deviation of real distribution of these two charges from point ones. To calculate $E_{Z}$ values optimized by $\gamma$ approximation, we applied a nonlinear method of the least squares. It minimizes root-mean-square deviation of a model field (expressions (3)) from measured field values. We also assumed that VG centroid value is at the minimum distance from the sensor at the time of field extreme value. For direct calculation we used a fragment of measurements away from the extremum within the data curve width on level 0.5. Measurement redundancy with large stock provided the possibility of such calculations.

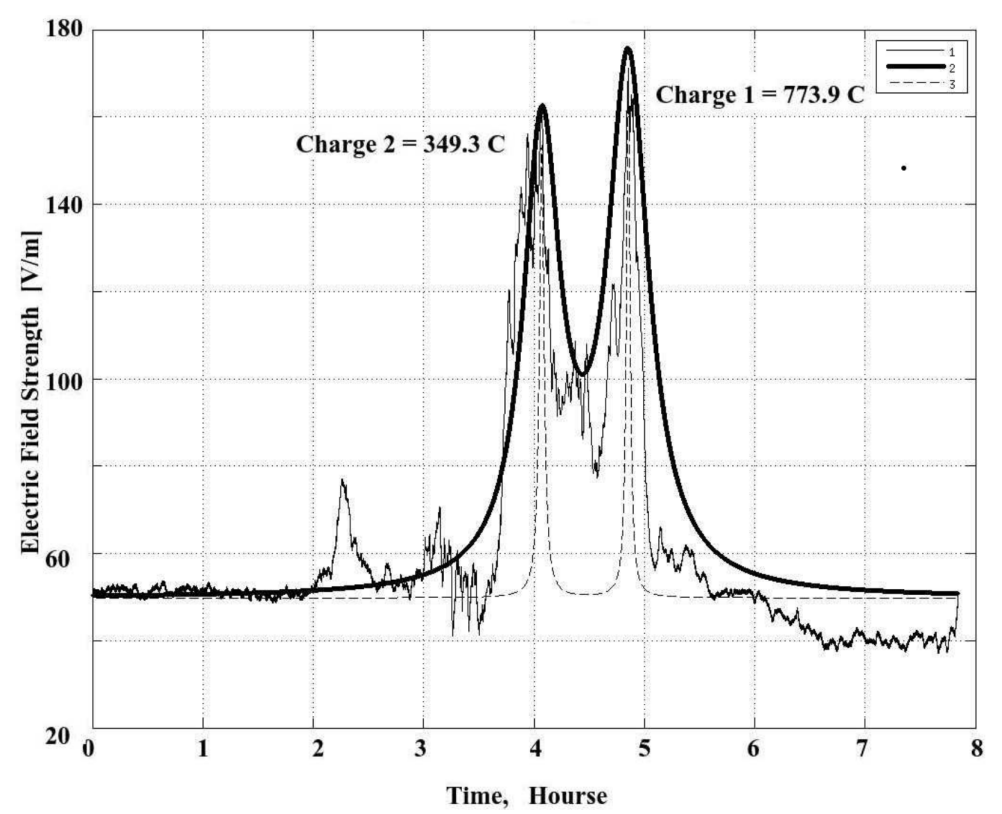

Figure 6. Modeling of AEF $E_{Z}$ response at KZY site on the passage of an EC from Shiveluch volcano eruption on 16 November 2014. 1-recorded data; 2-optimized approximation; 3-approximation by point charge. 
Application of approximation by point charges of extreme deviation of the sampling under consideration gives understated result. Using the approximation by a large number of point discharges of lower value and optimization with respect to parameter allowed us to obtain the estimates close to experimental ones and to calculate a more accurate value of the charge. For the bottom layer of a cloud propagating at the height of $9 \mathrm{~km}, \mathrm{Q}=349 \mathrm{C}$, and for the top layer $(11 \mathrm{~km}), \mathrm{Q}=774 \mathrm{C}$. That indicates that there is much more ash in the upper layer of the cloud formed due to the eruption than in the lower layer which was formed due to the convergence of pyroclastic flows. That is confirmed by direct observations at KLY site. At the same time aero-electric structure without charge steep gradient appears.

\subsubsection{Recording of Lightning Discharges Accompanying Explosive Eruptions in Kamchatka}

Examples of Lightning Discharge Records during Explosive Eruptions of Kamchatka Volcanoes

For the five strongest explosions of Shiveluch volcano in 2017 and two explosions of Bezymianny volcano in 2019 (http:/ / www.emsd.ru/ ssl/monitoring/main.htm), we considered explosive eruption parameters characterized by intensity and duration of magma fragmentation process [28] manifesting in electromagnetic and seismoacoustic radiation. For the Bezymianny volcano, maximum amplitudes of ground vibration rate from an explosive earthquake $\left(A_{\text {max }}^{z}\right)$ and those of overpressure in an air wave $(\Delta P)$ at KLY site, located $45 \mathrm{~km}$ from the volcano, were under consideration. Earthquake duration was determined by ground vibration data at SMK located $9 \mathrm{~km}$ from the volcano when the vibration amplitude was $A>\frac{1}{3} \cdot A_{\max }^{z}$.

During the events illustrated in Table 3, direction finding of radio pulses was carried out. It showed the presence of radio radiation sources in the direction of Shiveluch volcanoe. They may be associated with eruptive clouds. Figure 7 shows the counting rate for EP - N (pulses/min) with two-hour intervals during Shiveluch volcano eruptions.

For all the cases under consideration, two stages of EP generation are typical. They were previously detected during St. Augustine and Redoubt volcano eruptions in Alaska [5,6]. Both stages are clearly defined and are divided by the counting rate background values of 1-3 min. First stage interval of 2-5 $\mathrm{min}$ is associated with explosion beginning and thermal or turbulent stream formation.This assumption can be confirmed by the comparison of Shiveluch volcano eruptions. Figure $7 \mathrm{a}, \mathrm{b}$ illustrate the EP counting rate and the vertical component of ground vibration rate recorded during the events from Table 3. Having compared the parameters of explosive earthquakes (Figure $7 \mathrm{~b}$ ), we can assert that the velocity of ash-gas jet outflow in cases 1,3 and 4 was significantly higher than that in case 5. At the same time, according to the data presented in Figure 7a we see the converse. Intensity of the first stage of volcanic lightning was significantly lower in case 5 than that in cases 1,3 and 4. The second stage is associated with the formation of an erupted cloud at a hanging point near the tropopause height. It is obvious that the duration of volcanic lightning depends of the amount of erupted material. That is indicated by the correlation of pulse counting rate with $A_{z}$ max. A similar result was obtained in [29].

Electromagnetic pulses of the first and the second stages have significant differences. Durations of electromagnetic pulses of the first stage varies from $1.1 \cdot 10^{-4}(\mathrm{~s})$ to $7.8 \cdot 10^{-4}(\mathrm{~s})$ and spectral density maximum is at the frequencies of $35 \mathrm{kHz}$. During the second stage, they change from $10^{-2}$ (s) to 0.5 (s) and the maximum is at $10 \mathrm{kHz}$. These observations are fair for all the eruptions of Shiveluch and Bezymyanniy volcanoes under consideration. A similar result was obtained in [8].

The strongest explosions 1, 3, (Table 3) were accompanied by air waves with overpressure $\Delta P>20$ Pa recorded at KLY at the distance of $45 \mathrm{~km}$ from the volcano. That also indicates the relation of the intensity of volcanic lightning first stage with the initial velocity of ash-gas mixture. Seismic signal from air wave effect on the ground is clear for cases 1 and 3 (Figure 7b). 
Table 3. Description of eruptive and lightning activity of explosive eruptions of the Shiveluch volcano in 2017.

\begin{tabular}{ccccccccccccc}
\hline & & \multicolumn{4}{c}{ Explosion Characteristics } & \multicolumn{3}{c}{ Recorded EP Characteristics } \\
\hline No & Data & $\boldsymbol{t}_{\mathbf{0}}$ & $\mathbf{H}$ & $\boldsymbol{A}_{\text {max }}^{Z}$ & $\boldsymbol{\Delta} \boldsymbol{t}$ & $\boldsymbol{\Delta} \boldsymbol{P}$ & $\boldsymbol{\Delta} \boldsymbol{t}_{\mathbf{1}}$ & $\boldsymbol{C}_{\text {max }}$ & $\boldsymbol{N}_{\mathbf{1}}$ & $\boldsymbol{\Delta} \boldsymbol{t}_{\mathbf{2}}$ & $\boldsymbol{C}_{\max }$ & $\boldsymbol{N}_{\mathbf{2}}$ \\
\hline 1 & 11 May 2017 & $18: 24: 19$ & 10 & 18.5 & 11.2 & 37.9 & 4 & 13 & 36 & 28 & 12 & 144 \\
2 & 16 May 2017 & $07: 05: 52$ & 10 & 9.3 & 9.4 & 1.2 & 2 & 4 & 6 & 11 & 2 & 16 \\
3 & 14 June 2017 & $16: 26: 44$ & 12 & 8.1 & 6.5 & 22.9 & 3 & 20 & 41 & 10 & 7 & 42 \\
4 & 18 June 2017 & $16: 26: 57$ & 11 & 15.4 & 12.4 & 0.8 & 4 & 9 & 15 & 38 & 15 & 207 \\
5 & 23 July 2017 & $17: 43: 23$ & 8 & 2.7 & 48.5 & No data & 3 & 3 & 6 & 36 & 14 & 158 \\
\hline
\end{tabular}

Note. $\mathrm{H}$ is the eruptive cloud height based on satellite images, $\mathrm{km} ; A_{\max }^{Z}$ is the maximum amplitude of ground shift at $\mathrm{KLY}, \mu \mathrm{m} / \mathrm{s} ; \Delta t$ is the seismic event duration at $\mathrm{SMK}, \mathrm{min} ; \Delta P$ is overpressure amplitude during compression phase at KLY, $\mathrm{Pa} ; \Delta t_{1}, \Delta t_{2}$ are the durations of the first and the second stages of a volcanic thunderstorm, $\min ; C_{\max }$ is the maximum activity, pulse/min; $N_{1}, N_{2}$ are the EP total numbers in minute interval recorded during the first and the second stages of a volcanic thunderstorm.
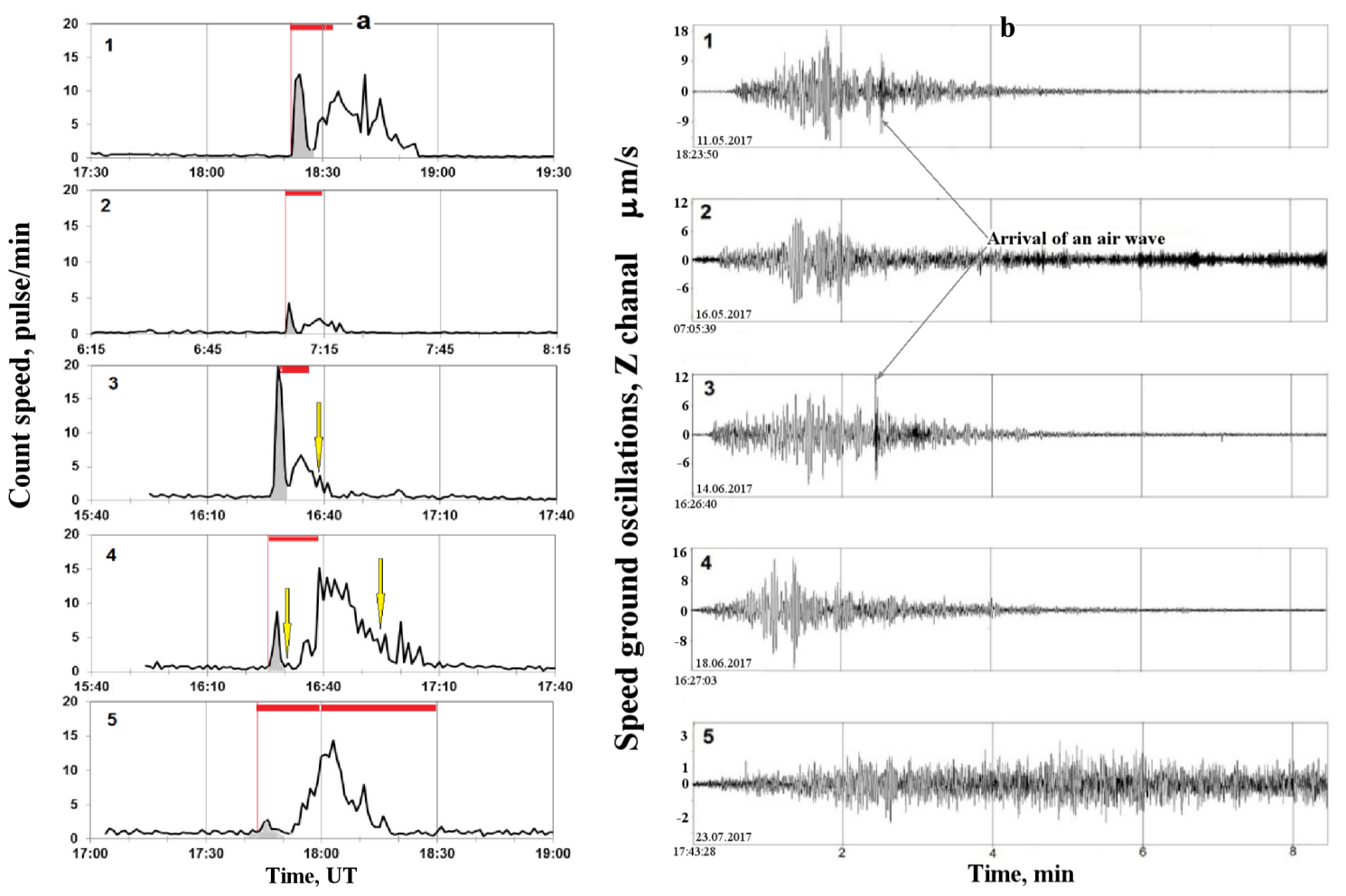

Figure 7. EP activity in minute intervals from the azimuth of $25.6 \pm 10^{\circ}$ to Shiveluch volcano (a), record of explosive earthquakes on the vertical component at KLY s/s (b). Panel numbers are according to Table 3. Arrows indicate lightning discharges recorded by WWLLN network and the squares show the seismic signal duration at SKR s/s.

During the Bezymyanniy volcano eruption on January 20 and March 2019, the VLF radio direction finder also recorded EP from the directions coinciding with volcano direction (Figure 8a,b). A description of the eruption and lightning-fast activity of the explosive eruptions of the Nameless Volcano in 2019 is presented in Table 4.

In contrast to the previous cases, only the second stage was observed on 20 January (Figure 8a), and a weak first and a very strong second stages were observed on 15 March 2019 (Figure 8b). We should also note that the eruption (on 15 March) began with a weak ejection at 17:13 during which the eruptive cloud reached the height of $\sim 3 \mathrm{~km}$ above the sea level. In this case the VLF radio direction finder did not record any stroke. Nine minutes later, at 17:21, a powerful burst was observed. As a result of it, the EC overcame the tropopause and reached the height of $16 \mathrm{~km}$. According to 
VLF radio direction finder, from that time volcanic activity developed. Activity of the first stage was 20 (pulses/min) and was close to the rates of the most active periods of EP during the observations over the events 1 and 3 of Shiveluch volcano (Figure 7). However, the number of discharges of the second stage significantly exceeds the analogous ones. It is likely to be associated with the difference between singular bursts of Shiveluch volcano and longer eruptions of Bezymyanniy volcano. Based on the data of temperature and wind stratification of the atmosphere, obtained during the sounding, the high-current discharges, recorded by WWLLN, occurred after erupted cloud passage through isotherm of $-25^{\circ} \mathrm{C}$, that agrees with $[25,30]$.

Table 4. Description of eruptive and lightning activity of explosive eruptions of the Bezymyanniy volcano in 2019.

\begin{tabular}{cccccccccccccc}
\hline & & \multicolumn{4}{c}{ Explosion Characteristics } & \multicolumn{4}{c}{ Recorded EP Characteristics } \\
\hline No & Data & $\boldsymbol{t}_{\mathbf{0}}$ & $\mathbf{H}$ & $\boldsymbol{A}_{\max }^{Z}$ & $\boldsymbol{\Delta} \boldsymbol{t}$ & $\boldsymbol{\Delta P}$ & $\boldsymbol{\Delta} \boldsymbol{t}_{\mathbf{1}}$ & $\boldsymbol{C}_{\max }$ & $\boldsymbol{N}_{\mathbf{1}}$ & $\boldsymbol{\Delta} \boldsymbol{t}_{\mathbf{2}}$ & $\boldsymbol{C}_{\max }$ & $\boldsymbol{N}_{\mathbf{2}}$ \\
\hline 1 & 20 January 2019 & $16: 05: 58$ & 15 & 45.4 & 15.2 & No Data & - & - & - & 19 & 22 & 206 \\
2 & 15 March 2019 & $17: 12: 05$ & 16 & 58.5 & 35.4 & $>39.7$ & 5 & 32 & 93 & 51 & 88 & 1043 \\
\hline
\end{tabular}

Note. $\mathrm{H}$ is the eruptive cloud height based on satellite images, $\mathrm{km} ; A_{\max }^{Z}$ is the maximum amplitude of ground shift at KLY, $\mu \mathrm{m} / \mathrm{s} ; \Delta t$ is the seismic event duration at KLY, min; $\Delta P$ is overpressure amplitude during compression phase at KLY, Pa; $\Delta t_{1}, \Delta t_{2}$ are the durations of the first and the second stages of a volcanic thunderstorm, $\min ; C_{\max }$ is the maximum activity, pulse/min; $N_{1}, N_{2}$ are the EP total numbers in minute interval recorded during the first and the second stages of a volcanic thunderstorm.
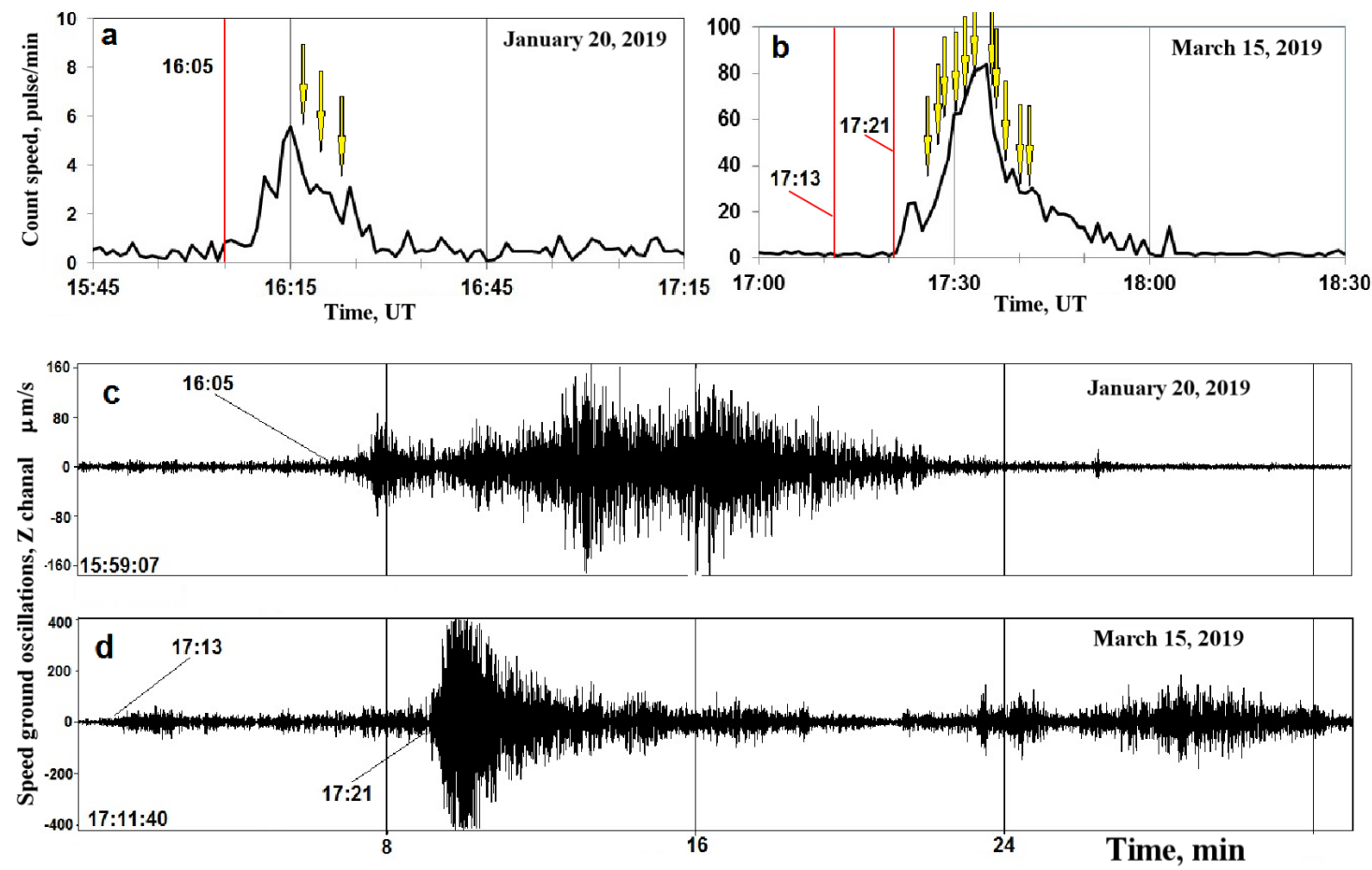

Figure 8. EP activity in minute intervals from the azimuth of $25.6 \pm 10^{\circ}$ to Bezymianny volcano on 20 January 2019 (a) and on 15 March 2019 (b), record of explosive earthquakes of the vertical component at KIR station s/s (c,d). Arrows show lightning discharges recorded by WWLLN network.

\section{Conclusions}

Records of AEF vertical component in the near ground atmosphere near active volcanoes allow us to detect the presence of erupted clouds even weakly saturated with ash. The sites network for AEF Ez observations near erupting volcanoes makes it possible to detect and to estimate the trajectory of motion of an erupted cloud, the degree of saturation with fine ash. Observations over electric processes in erupted clouds can be one of the components of complex observations over volcano eruptions to assess the hazard for flights. In the future we plan to develop a network of sites to monitor AEF Ez near 
active volcanoes of Kamchatka. Electrostatic inhomogeneities in EC give us the ground to consider it as a complex of single volumes with characteristic size of charge spatial homogeneity (volcanic globule). Mathematical modeling with VG approximation by point charge field for Shiveluch volcano EC showed acceptable results.

Based on the data described above, EP records accompanying the explosive eruptions of Kamchatka volcanoes, the presence of two stages of a volcanic thunderstorm was confirmed. EP registration also improves the effectiveness of ash hazard assessments for airliners on numerous routes along the eastern coast of Kamchatka. In order to do than we plan to install VLF radio direction finders at KZV and KBG sites in the nearest future. When choosing the places for new sites we considered their closeness to potential objects for observations. These objects are the most active volcanoes of the Northern Group of Volcanoes.

WWLLN network does not record weak EP from strokes occurring in erupted clouds. However, during the drift of the ash cloud and its interaction with the surrounding atmosphere, powerful lightning strokes occur. Thus, during the eruptions 3 and 4, the WWLLN recorded lightning strokes which occurred at the front of an erupted cloud when it reached the buoyancy height (Figure 7 , panels 3,4). During a long emission of mass and heat which occurs during powerful eruptions of andesitic volcanoes with pyroclastic flow formation, one should expect significant electrification of EC accompanied by powerful lightning, ejections from which are recorded by WWLLN network.

Author Contributions: Conceptualization P.P.F. and G.I.D.; methodology P.P.F.; software E.I.M.; validation E.I.M., R.R.A. and N.V.C.; formal analysis V.N.U. and P.P.F.; investigation P.P.F., R.R.A., E.I.M.; resources I.E.S.; data curation E.I.M. and R.R.A.; writing-original draft preparation P.P.F., V.N.U. and G.I.D.; writing-review and editing N.V.C., R.H.H.; visualization E.I.M., R.R.A.; supervision N.V.C.; project administration G.I.D.; funding acquisition G.I.D. All authors have read and agreed to the published version of the manuscript.

Funding: The work was partially supported by the RFBR Grants No. 19-05-00543, 18-35-00175.

Conflicts of Interest: The funders had no role in the design of the study; in the collection, analyses, or interpretation of data; in the writing of the manuscript, or in the decision to publish the results.

\section{Abbreviations}

The following abbreviations are used in this manuscript:

EC Eruptive Cloud

$\mathrm{AEF} E_{Z} \quad$ Atmospheric Electric Field vertical component

EP Electromagnetic Pulses

VLF Very Low Frequency

KB FRC GS RAS Kamchatka Branch of the Federal Research Center "Geophysical Survey RAS"

KLY Klyuchi sites

KZY Kozyrevsk sites

KBG Krutoberegovo sites

SKR Severo-Kuril'sk sites

SMK Semkorok seismic station

BDR Baidarnaia seismic station

WWLLN World Wide Lightning Location Network

GEC global electrical circuit

VG volcanic globule

\section{References}

1. Mather, T.A.; Harrison, R.G. Electrification of volcanic plumes. Serv. Geophys. 2006, 27, 387-432. [CrossRef]

2. McNutt, S.R. Volcanic lightning: Global observations and constraints on source mechanisms. Bull. Volcanol. 2010, 72, 1153-1167. [CrossRef]

3. Rodger, C.J.; Brundell, J.B.; Dowden, R.L. Location accuracy of VLF World Wide Lightning Location (WWLL) network: Post-algorithm upgrades. Ann. Geophys. 2005, 23, 277-290. [CrossRef] 
4. Woodhouse, M.J.; Behnke, S.A. Charge structure in volcanic plumes: A comparison of plume properties predicted by an integral plume model to observations of volcanic lightning during the 2010 eruption of Eyjafjallajokull, Iceland. Bull. Volcanol. 2014, 76, 828. [CrossRef]

5. Thomas, R.J.; McNutt, S.R.; Krehbiel, R.P.; Rison, W.; Aulich, G.; Edens, H.E.; Tytgat, G.; Clark, E. Lightning and electrical activity during the eruptions of Augustine volcano. US Geol. Surv. Prof. Pap. 2010, 1769, 579-608.

6. Behnke, S.A.; Thomas, R.J.; McNutt, S.R.; Schneider, D.J.; Krehbiel, P.R.; Rison, W.; Edens, H.E. Observations of volcanic lightning during the 2009 eruption of Redoubt Volcano. J. Volcanol. Geotherm. Res. 2013, 259, 214-234. [CrossRef]

7. Firstov, P.P.; Akbashev, R.R.; Holzworth, R.; Cherneva, N.V.; Shevtsov, B.M. Atmospheric Electric Effects during the Explosion of Shiveluch Volcano on November 16, 2014. Izv. Atmos. Ocean. Phys. 2017, 53, $24-31$. [CrossRef]

8. Hargie, K.A.; Van Eaton, A.R.; Mastin, L.G.; Holzworth, R.H.; Ewert, J.W.; Pavolonis, M. Globally detected volcanic lightning and umbrella dynamics during the 2014 eruption of Kelud, Indonesia. J. Volcanol. Geotherm. Res. 2019, 382, 81-91. [CrossRef]

9. Hutchins, M.L.; Holzworth, R.H.; Rodger, C.J.; Brundell, J.B. Far field power of lightning strokes as measured by the World Wide Lightning Location Network. J. Atmos. Ocean. Technol. 2012, 29, 1102-1110. [CrossRef]

10. Cherneva, N.V.; Mel'nikov, A.N.; Holzworth, R.H.; Ivanov, A.V.; Druzhin, G.I.; Firstov, P.P. Identifcation of lightning with ash clouds of explosive eruptions in Kamchatka. In Solar-Terrestrial Relations and Physics of Earthquake Precusors: VI International Conference, Paratunka, Kamchatksiy kray, 9-13 September 2013: Book of Abstracts; Shevtsov, B.M., Ed.; IKIR FEB RAS: Petropavlovsk-Kamchatskiy, Russia, 2013; pp. 360-365.

11. Smith, C.; Said, R.; Eaton, A.V. Volcanic lightning as a monitoring tool during the 2016-2017 eruption of Bogoslof Volcano, AK. In Proceedings of the 25th International Lighting Detection Conference, Fort Lauderdale, FL, USA, 12-15 March 2018; pp. 1-7.

12. Cherneva, N.V.; Firstov, P.P. Formation of the local electric field of the atmosphere in Kamchatka under the influence of natural processes. In Formation of the Local Electric Field of the Atmosphere in Kamchatka under the Influence of Natural Processes; Dalnauka: Vladivostok, Russia, 2018; 134p.

13. Efimov, V.A.; Oreshkin, D.M.; Firstov, P.P.; Akbashev, R.R. EF-4 Electromagnetic Fluxmeter for Studies of Geodynamic Processes. Seism. Instrum. 2014, 50, 230-237. [CrossRef]

14. Budilov, D.I.; Akbashev, R.R.; Firstov, P.P. Development of hardware-Software complex for registration the atmospheric electric potential gradient. In Proceedings of the 10th Biennual Workshop on Japan-KamchatkaAlaska Subduction Processes (JKASP-2018), Petropavlovsk-Kamchatsky, Russia, 20-26 August 2018; pp. 34-35. Available online: http:/ /www.kscnet.ru/ivs/conferences/jkasp2018/pdf/BudilovDI_99-107.pdf (accessed on 18 February 2020).

15. Behnke, S.A.; McNutt, S.R. Using lightning observations as a volcanic eruption monitoring tool. Bull. Volcanol. 2014, 76, 2-12. [CrossRef]

16. Druzhin, G.I.; Pukhov, V.M.; Sannikov, D.V.; Malkin, E.I. VLF lightning direction finder. Bull. KRAESC Phys. Math. Sci. 2019, 2, 95-104.

17. Druzhin, G.I.; Cherneva, N.V.; Melnikov, A.N. Thunderstorm near the Kamchatka Peninsula according to observations of VLF radiation. Meteorol. Hydrol. 2011, 7, 32-39.

18. The nature of volcanic processes in Kamchatka, Volcanoes of Northern Kamchatka and the Middle Ridge. In Active Volcanoes of Kamchatka; Fedotov, S.A., Masurenkov, Y.P., Eds.; Nauka: Moscow, Russia, 1991; 304p.

19. Firstov, P.P.; Akbashev, R.R.; Zharinov, N.A.; Maksimov, A.P.; Manevich, T.M.; Mel'nikov, D.V. Electrification of eruptive plumes discharged by Shiveluch volcano in relation to the character of the responsible explosion. Volcanol. Seismol. 2019, 13, 172-184. [CrossRef]

20. Melekestsev, I.V.; Dvigalo, V.N.; Kiryanov, V.Y.; Kurbatov, A.V.; Nesmachnyi, I.A. Ebeko Volcano (Kuril Islands): A history of eruptive activity and future volcanic hazard. Part 2. Volcanol. Seismol. 1993, 4, 24-41.

21. Volcanoes of Eastern Kamchatka, Volcanoes of South Kamchatka. In Active Volcanoes of Kamchatka; Fedotov, S.A., Masurenkov, Y.P., Eds.; Nauka: Moscow, Russia, 1991; 304p.

22. Kotenko, T.A.; Sandimirova, E.I.; Kotenko, L.V. The 2016-2017 eruptions of Ebeko Volcano (Kuriles Islands). Vestnik KRAUNTs Seriya «Nauki o Zemle» 2018, 37, 32-42. 
23. Shevtsov, B.M.; Firstov, P.P.; Cherneva, N.V.; Holzworth, R.H.; Akbashev, R.R. Lightning and electrical activity during the Shiveluch volcano eruption on 16 November 2014. Nat. Hazard Earth Syst. Sci. 2016, 16, 871-874. [CrossRef]

24. Cherneva, N.V.; Ponomarev, Y.A.; Firstov, P.P.; Buzevich, A.V. Basic models of sources of variations of the vertical component of the atmospheric electric field. Vestn. Kamchatskoy Reg. Assotsiatsii «Uchebno-Nauchnyy Tsentr» Seriya Nauk. O Zemle 2007, 2, 66-64.

25. Van Eaton, A.; Schneider, D.J.; Smith, C.M.; Haney, M.M.; Lyons, J.J.; Said, R.; Fee, D.; Holzworth, R.H.; Mastin, L.G. Did ice-charging generate volcanic lightning during the 2016-2017 eruption of Bogoslof volcano, Alaska. Bull. Volcanol. 2020, 82, 34. [CrossRef]

26. Rossi, E.; Bonadonna, C.; Degruyter, W.A. A new strategy for the estimation of plume height from clast dispersal in various atmospheric and eruptive conditions. Earth Planet. Sci. Lett. 2019, 505, 1-12. [CrossRef]

27. Woods, A.W. The fluid-dynamics and thermodynamics of eruption columns. Bull. Volcanol 1988, 50, $169-193$. [CrossRef]

28. Zobin, V.M. Volcano Seismology: An Introduction. In Encyclopedia of Complexity and Systems Science; Meyers, R., Ed.; Springer: Berlin, Germany, 2017; 559p.

29. Van Eaton, A.R.; Amigo, A.; Bertin, D.; Mastin, L.G.; Giacosa, R.E.; González, J.; Valderrama, O.; Fontjin, K.; Behnke, S.A. Volcanic lightning and plume behavior reveal evolving hazards during the April 2015 eruption of Calbuco volcano, Chile. Res. Lett. 2016, 43, 3563-3571. [CrossRef]

30. Arason, P.; Bennett, A.J.; Burgin L.E. Charge mechanism of volcanic lightning revealed during the 2010 eruption of Eyjafjallajökull. J. Geophys. Res. 2011, 116, B00C03. [CrossRef]

(C) 2020 by the authors. Licensee MDPI, Basel, Switzerland. This article is an open access article distributed under the terms and conditions of the Creative Commons Attribution (CC BY) license (http:/ / creativecommons.org/licenses/by/4.0/). 